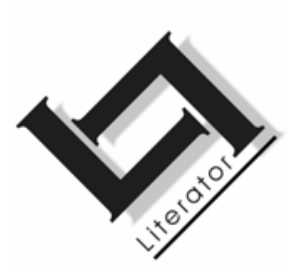

\title{
Humor in kinderverhale in die tersiêre en intermediêre fases van taalonderwys
}

\author{
Jani van Niekerk \\ Institusionele Inligting \\ Universiteit van Johannesburg \\ AUCKLANDPARK \\ E-pos: janivn@operamail.com
}

\author{
Betsie van der Westhuizen \\ Skool vir Tale \\ Potchefstroomkampus \\ Noordwes-Universiteit \\ POTCHEFSTROOM \\ E-pos: afnesvdw@puk.ac.za
}

\begin{abstract}
Humour in children's literature in the tertiary and intermediate phases of language education
\end{abstract}

Humour is essential in the development of an individual and in the development of a healthy society in general, and research on humour is currently regarded as important in a variety of disciplines in the humanities. There are various ways in which an individual may be exposed to humour, and one of these is children's stories. An instrument or model for studying humour in children's stories is necessary and very useful: an instrument that takes into account developmental psychology, literary theory and the nature of humour. When these are combined, the nature, scope and effect of humour in children's stories can be determined. This article explores ways in which such a model can be used at tertiary level in undergraduate and graduate studies, in teacher training and at the intermediate level when facilitating reading as one of the learning aims in language teaching to children from eight to twelve years (roughly Grades 4 to 6). Humour can be an instrument in the hands of authors and of adults as mediator or facilitator to sensitise young readers to humour in stories. As a consequence of this process of sensitising, readers' reading and life skills are developed and their horizon of experience is broadened.

\section{Opsomming}

Humor in kinderverhale in die tersiêre en intermediêre fases van taalonderwys

Humor is noodsaaklik vir die ontwikkeling van die individu en vir die geestesgesondheid van 'n samelewing, en navorsing oor humor word 
tans beskou as belangrik in 'n groot verskeidenheid dissiplines in veral die geesteswetenskappe. Daar is talle wyses waarop ' $n$ individu aan humor blootgestel kan word; een hiervan is die lees van kinderverhale. ' $n$ Instrument of model vir die bestudeer van humor in kinderverhale is noodsaaklik en besonder nuttig: 'n instrument waarin ontwikkelingspsigologie, literatuurteorie en humorteorieë verreken is. Indien hierdie drie gekombineer word, kan die aard, reikwydte en effek van humor bepaal word. In hierdie artikel word wyses ondersoek waarop so 'n model geïmplementeer kan word op tersiêre vlak in voor- en nagraadse onderrig - in talestudies en in onderwysersopleiding, asook in die intermediêre fase - wanneer leesfasilitering gedoen word as een van die leeruitkomste vir taalonderwys vir agt- tot twaalfjariges, gewoonlik in graad 4 tot 6 . Humor kan 'n instrument wees waarmee die outeur idees oordra, asook 'n instrument vir die volwassene as medieerder of fasiliteerder. Volwassenes kan 'n kind sensitief maak vir humor in kinderverhale en daardeur kan kinders/leerders se lees- en lewensvaardighede ontwikkel en hulle ervaringshorison verruim word.

\section{Humor - ter inleiding}

"Die (volks)nar is dood - lank lewe die nar." Met hierdie woorde bevestig Wilhelm Jordaan (2000:12) die universaliteit, die durende aard en noodsaaklikheid van humor vir die individu en vir die samelewing. Humor manifesteer op verskillende wyses in verskillende kontekste en word oor verskeie dissiplines heen beskou as 'n belangrike faktor in die mens se ontwikkeling (Braude, 1996:94; Gordon, 1996:203-206; Podilchak, 1992:383-385; Steenberg, 1987: 13; White \& Winzelberg, 1992:343-355).

Sonder humor, sê Marita de Sterck (1997:109), is geen groei moontlik nie. Elsabe Steenberg (1987:13) stel dit ietwat anders, maar dit kom op dieselfde neer: die ontwikkeling van 'n sin vir humor dui op 'n patroon van vooruitgang en groei.

Die kind se wêreld word in 'n besondere mate gevorm deur die media waarmee hy of sy in aanraking kom, byvoorbeeld boeke, tydskrifte, televisie en die Internet. Humor in kinderliteratuur kan 'n uitstekende middel wees om 'n leeskultuur te help bevorder. Dit kan ook op individueel-psigologiese vlak sowel as op literêr-sosiologiese vlak, 'n heilsame en positiewe invloed hê. Dit is noodsaaklik dat 'n jong leser plesier put uit wat hy lees sodat dit hom motiveer om steeds meer te wil lees. Die ontwikkeling van 'n sin vir humor ontsluit emosionele, intellektuele en normatiewe wêrelde en kan bydra tot die ontwikkel van 'n gesonde lewens- en wêreldbeskouing. 
Die doel van hierdie artikel is om 'n humormodel voor te stel wat gebruik kan word om humor in kinderverhale te bestudeer, onder andere in tersiêre onderrig in byvoorbeeld talekursusse/-modules en vakdidaktiek in onderwysersopleiding, sodat dit onder andere aangepas en toegepas kan word in die fasilitering van humor in kinderverhale in intermediêre onderrig. Die doel is nie om gedetailleerde leerervarings uiteen te sit nie, maar om kernaspekte om humor in kinderverhale in die tersiêre en intermediêre fases van taalonderwys te integreer.

\section{Humor, kinders en kinderliteratuur}

Ten spyte daarvan dat alle mense 'n aangebore sin vir humor het (Tucker, 1988:67), is dit nie noodwendig so dat alle mense se vaardigheid ten opsigte van die begryp en gebruik van humor ten volle ontwikkel is nie. Die kweek van 'n sin vir humor is in die hande van die volwasse rolspelers in 'n kind se lewe: dit sluit ouers, onderwysers en ander individue in.

Dit is belangrik dat ' $n$ volwassene sal kennis dra van die waarde van humor in kinderliteratuur. Jan van Coillie (1999:95-99) noem onder andere die volgende redes waarom humor in kinderliteratuur waarde inhou vir die jong leser. Humor bied 'n uitlaatklep vir spanning; 'n dosis aggressiewe humor, veral as dit gekombineer word met fantasie, help dikwels om grieselrige en bedreigende dinge te laat verminder of verdwyn. Humor help die kind om angste en probleme te oorkom en te oorwin, omdat 'n humoristiese benadering dikwels die intensiteit van probleme kan relativeer. Lag werk bevrydend ten opsigte van vele verbode dinge en beperkinge wat in die daaglikse lewe aan die kind opgelê word. Met humor kan die grense van die toelaatbare afgebaken word. Deur kattekwaad en grappe kan kinders byvoorbeeld agterkom hoe ver hulle kan gaan. Deur speelse aggressie sneuwel taboes, soos die lees of uitspreek van "verbode" woorde. Humor stimuleer kreatiwiteit. Fantasie en verbeelding, wat sleutelbegrippe is by humor, bied 'n kind moontlikhede om die werklikheid kreatiewer en weerbaarder tegemoet te gaan: "Humor stimuleert de creativiteit en bevrijdt ons uit onze logische, praktische en rechtlijnige manier van denken" (Van Coillie, 1999:96). Humor is ook 'n middel tot sosialisering; 'n kind wat 'n goeie of fyn sin vir humor het, is dikwels meer populêr as kinders wat bot is. Die suksesvolle integrering van humor in die individu se algehele ontwikkeling dra by tot ' $n$ positiewe selfkonsep. Wat interaksie met ander betref, kan humor bydra tot positiewe en suksesvolle interpersoonlike verhoudinge. 
Dit is ook so dat die ontwikkel van 'n sin vir humor gedurende 'n mens se lewe deur verskillende fases gaan; mense vind verskillende dinge op verskillende lewenstadia om verskillende redes humoristies. Omdat in hierdie artikel gefokus word op verhale vir die middelkinderjare (ongeveer agt tot twaalf jaar), word slegs op enkele aspekte aangaande die ontwikkel van humorsin tydens spesifiek hierdie fase gewys. Van Coillie (1999:99-105) het bevind dat die meeste humornavorsers die periode tussen nege en twaalf jaar as die mees humorgevoelige tydperk in 'n kind se taalontwikkeling beskou. Daarom is dit so dat in geen ander stadium van 'n kind se lewe grapboeke juis so gewild is soos in hierdie fase nie. Van Coillie verduidelik voorts dat kinders tussen sewe en twaalf jaar besef dat woorde meerduidig kan wees. Daarom geniet hulle woordspeling, omdat dit berus op die gelyktydige insien van die veelvuldige betekenisse van woorde. Idiomatiese uitdrukkings wat letterlik geïnterpreteer word, asook raaiselgrappe is baie gewild. Kinders op hierdie ouderdom se morele ontwikkeling en humorontwikkeling gaan hand aan hand. Hulle geniet byvoorbeeld humoristiese dinge in 'n verhaal wat hulle self nie sou durf sê of doen nie. Die karikatuuragtige neerhaal van volwassenes in gesagsposisies is tipies van dié fase waarin die kind al meer en meer sy eie pad selfstandig probeer vind. Die populêrste soort humor op hierdie ouderdom is klugtigheid (slapstick, soos struikel, in die modder beland, met terte gooi, of 'n pannekoek op die kop) en taboeverbreking (soos byna-byna-vloekwoorde en die oorboord gooi van goeie maniere). Veral vanaf ongeveer tien jaar is die kombinasie van spanning en humor heel gewild.

\section{Humor in uitkomsgerigte literatuuronderwys (tersiêr) en leesfasilitering (intermediêr)}

Die navorsingsvraag wat ontstaan, is die volgende: hoe kan humor geïntegreer word in die kurrikulum in voor- en nagraadse literatuuronderrig (onder andere vakdidaktiekonderrig op tersiêre vlak) sodat studente toegerus kan word om dit weer op skoolvlak aan leerders oor te dra? 'n Onderwyser as fasiliteerder moet weet op watter vlak hy/sy bepaalde kennis en vaardighede moet fasiliteer, maar hy/sy moet dit altyd doen vanuit ' $n$ posisie van meerdere kennis en kundigheid. ${ }^{1}$ Dit is dus nie voldoende dat byvoorbeeld onderwys-

1 Die term opvoeder is gebruiklik sedert uitkomsgerigte onderwys formeel in die negentigerjare van die 20ste eeu ingestel is, maar teenswoordig word die term opvoeder weer spontaan uitruilbaar met die term onderwyser gebruik. Die term opvoeder (met verwysing na die onderwyser of fasiliteerder) is problematies in 
studente slegs die humortipes leer wat hy/sy sal nodig kry om aan leerders in die laer- en hoërskool te fasiliteer nie; die student as volwassene moet aan 'n groot spektrum inligting blootgestel word, sodat hy/sy die beroepswêreld met 'n groot korpus kennis en diepte van insig sal betree en uitnemende onderrig sal kan gee.

In 'n polisistemiese benadering tot kinderliteratuur in die onderrig is dit noodsaaklik dat in voor- en nagraadse kurrikulums aandag gegee word aan die verskeidenheid wyses waarop humor in kinderverhale in die geesteswetenskappe kan figureer (Van der Westhuizen, 1999: 134-135). Humor in kinderliteratuur kan in talle dissiplines in tersiêre onderrig betrek word. Die mees voor die hand liggende is in voor-en nagraadse talekursusse/-modules, inligtingkunde, grafiese ontwerp, skryfkuns, vertaalkunde, die uitgewerswese, kommunikasiekunde, asook in vakdidaktieke van tale. Die rede waarom ook op die intermediêre fase (Graad 4 tot 6) gefokus word, is omdat al drie die tekste wat gekies is vir hierdie artikel, geskik is vir dié onderrigfase en juis omdat die ouderdomsfase agt tot twaalf jaar so 'n besonder belangrike fase is in die kind se ontwikkeling van 'n goeie en fyn sin vir humor. Daar sal telkens net na enkele fasette van die onderrig in uitkomsgerigte onderrig-terme: fasilitering - verwys word. Wat wel belangrik is, is om die kritieke uitkomste, die addisionele uitkomste en die leeruitkomste vir tale in berekening te bring. Weens die beperkte omvang van die artikel word hierdie uitkomste nie hier uiteengesit nie; dis egter maklik bekombaar in enige amptelike dokumentasie oor uitkomsgerigte onderrig, soos die Revised National Curriculum Statements (Departement van Onderwys, 2002).

\section{Die humormodel}

Om spontaan te lag oor iets gee mense van alle ouderdomme van kortstondige plesier tot 'n diepe vreugde, maar kennis van en insig in die aard en waarde van humor is ' $n$ handige hulpmiddel in die fasilitering van lees en van taalonderwys oor die algemeen.

Uit ondersoeke na kinderverhale word dit duidelik dat talle vorme van humor daarin voorkom. In die oorspronklike navorsing (Van Niekerk, 2001) het die navorsingsmetodes literatuurstudie en teksstudie behels. In die bestudering van tersaaklike vakliteratuur is

'n sin waarin daar tussen die onderwyser en die ouer onderskei wil word - die ouer is immers ook ' $\mathrm{n}$ opvoeder. Die term fasiliteerder word veral gebruik wanneer daar na die vakonderwyser-in-aksie in die klaskamer verwys word. 
onder meer op ontwikkelingpsigologie, literatuurteorie en humor ingegaan. Uit 'n verskeidenheid humorteorieë, soos uiteengesit en beredeneer deur onder andere Attardo (1994), Baudoin (1994), Bergson (1911), Braude (1996), Durant en Miller (1988), Gruner (1978), Lowis en Nieuwoudt (1994), Podilchak (1992) en Raskin (1985) is 'n sintese gevorm met betrekking tot 'n aantal tipes wat gebruik kan word om humor in kinderverhale vir kinders van nege tot twaalf jaar mee te beskryf. Die model dien dus as instrument by die ontleding van humor in kinderverhale. Binne hierdie model word drie hooftipes humor onderskei: a) situasiehumor, b) woordhumor en c) humor gesetel in tekstipografie en illustrasies.

\subsection{Situasiehumor}

Situasiehumor kan gedefinieer word as die humor wat gesetel is in en ontstaan deur die situasies waarin karakters, gebeure, ruimte, tyd, fokalisasie en vertelwyse met mekaar in interaksie tree. Vervolgens word situasiehumor skematies uiteengesit (Van Niekerk, 2001:54-57).

\begin{tabular}{|l|l|l|}
\cline { 2 - 3 } \multicolumn{1}{l|}{} & Subtipe & Beskrywing \\
\hline (1) & Antiklimaks & $\begin{array}{l}\text { 'n Situasie wat opgebou het, is skielik } \\
\text { afgeloop. Die humor is gesetel in die } \\
\text { skielike verbreking van die verwagting. }\end{array}$ \\
\hline (3) & Geid & $\begin{array}{l}\text { Dit word gebruik om 'n karakter te beskryf } \\
\text { wat meganies optree. In sulke optrede } \\
\text { word logika slegs beperk aangewend of } \\
\text { ontbreek dit heeltemal. }\end{array}$ \\
\hline $\begin{array}{l}\text { Dit is fisiese aktiwiteite met ernstige } \\
\text { gevolge. Op die vraag hoekom geweld } \\
\text { snaaks is, kan geantwoord word dat die } \\
\text { leser meerderwaardig of partydig voel } \\
\text { teenoor een of meer van die partye wat in } \\
\text { die geweld betrokke is. 'n Tweede moont- } \\
\text { likheid is dat die leser deur vorige bloot- } \\
\text { stellings aan fiktiewe geweld gekondisio- } \\
\text { neer is om te weet dat dié geweld nie } \\
\text { werklik ernstig is nie. Kinders word } \\
\text { byvoorbeeld reeds vanaf 'n vroeë ouder- } \\
\text { dom blootgestel aan tekenprentgeweld. }\end{array}$ \\
\hline
\end{tabular}




\begin{tabular}{|c|c|c|}
\hline (4) & Herkenning & $\begin{array}{l}\text { Die leser kan 'n karakter of gebeure } \\
\text { herken vanweë die ooreenkomste wat } \\
\text { daar bestaan tussen die elemente in die } \\
\text { verhaal en die ekwivalente daarvan in die } \\
\text { werklike lewe. }\end{array}$ \\
\hline (5) & $\begin{array}{l}\text { Indirekte } \\
\text { bevestiging }\end{array}$ & $\begin{array}{l}\text { 'n Gevoel van meerderwaardigheid } \\
\text { ontstaan by die leser, omdat sy ver- } \\
\text { moedens bevestig word. }\end{array}$ \\
\hline (6) & Inkongruensie & Dit is alle onlogiese situasies. \\
\hline (7) & Ironie & $\begin{array}{l}\text { Een ding word verwag, maar 'n ander } \\
\text { gebeur, sodat situasionele ironie ont- } \\
\text { staan. }\end{array}$ \\
\hline (8) & Klugtigheid & $\begin{array}{l}\text { Dit is fisiese aktiwiteite wat per ongeluk } \\
\text { voorkom en geen ernstige gevolge het } \\
\text { nie. }\end{array}$ \\
\hline (9) & Misverstand & $\begin{array}{l}\text { Misverstand ontstaan tussen karakters as } \\
\text { gevolg van verskillende persepsies of } \\
\text { grade van ingeligtheid. Die humor is veral } \\
\text { gesetel in die feit dat die leser presies } \\
\text { kan sien waar die probleem ontstaan. }\end{array}$ \\
\hline$(10)$ & Oordrywing & $\begin{array}{l}\text { Oordrywing behels dat 'n saak vergroot } \\
\text { word. }\end{array}$ \\
\hline (11) & Penaries & $\begin{array}{l}\text { Dit beskryf situasies waar die karakter } \\
\text { onverwags in 'n benarde situasie beland } \\
\text { en nie weer daar kan uitkom nie. }\end{array}$ \\
\hline$(12)$ & Peripetie & $\begin{array}{l}\text { Wanneer daar van situasies verwissel } \\
\text { word op so ' } n \text { manier dat dit inkongruent } \\
\text { of verrassend is. }\end{array}$ \\
\hline (13) & Sarkasme & $\begin{array}{l}\text { Dit kom veral voor in dialoog tussen } \\
\text { karakters en behels dat karakters iets } \\
\text { anders sê as wat hulle in werklikheid } \\
\text { bedoel. Hierdie tipe humor is besonder } \\
\text { afhanklik van die taaltekstuur van die teks } \\
\text { waarbinne dit voorkom. }\end{array}$ \\
\hline
\end{tabular}




\begin{tabular}{|l|l|l|}
\hline (14) & $\begin{array}{l}\text { Skep van verwag- } \\
\text { tings }\end{array}$ & $\begin{array}{l}\text { Die leser word as 't ware voorberei op } \\
\text { gebeure. Die gebeure self is nie nood- } \\
\text { wendig humoristies nie, maar die ver- } \\
\text { wagting dat iets gaan gebeur waarvan die } \\
\text { karakters nie bewus is nie, maak dit } \\
\text { humoristies. }\end{array}$ \\
\hline$(15)$ & Spottery & $\begin{array}{l}\text { Karakters haal mekaar verbaal oor die } \\
\text { kole op 'n humoristiese wyse. Daar kan } \\
\text { ook deur die verteller met karakters of } \\
\text { situasies gespot word. }\end{array}$ \\
\hline$(16)$ & Taboeverbreking & $\begin{array}{l}\text { Verskillende soorte konvensies word } \\
\text { oortree. }\end{array}$ \\
\hline$(17)$ & Terugwysing & $\begin{array}{l}\text { Daar word op 'n subtiele manier terug- } \\
\text { verwys na 'n situasie/gebeurtenis. Deur } \\
\text { hierdie terugwysing roep die leser dan die } \\
\text { vorige situasie op en hierdie herinnering } \\
\text { is humoristies. }\end{array}$ \\
\hline$(19)$ & Verrassing & $\begin{array}{l}\text { lets van waarde word vergelyk met iets } \\
\text { relatief onbelangriks, en die karakter(s) } \\
\text { kan nie die diskrepansie agterkom nie. }\end{array}$ \\
\hline $\begin{array}{l}\text { Dit verskil van inkongruensie in dié sin } \\
\text { dat dit nie onlogies is nie, maar wel } \\
\text { onverwags. }\end{array}$ \\
\hline
\end{tabular}

\subsection{Woordhumor}

Woordhumor is die aanwending van humortipes op die vlak van die tekstekstuur. Meestal is dit in 'n enkele sin of woord gesetel. Die kategorieë wat bespreek is deur Van Niekerk (2001:47-58), is gebruik as riglyn vir die keuse van soorte woordhumor, maar as toevoeging is algemene beeldspraak en stylfigure (Cloete, 1992; Van Gorp et al., 1991) ook gebruik. Humor op tekstuurvlak kan skematies soos volg uiteengesit word (Van Niekerk, 2001:57-58): 


\begin{tabular}{|c|c|c|}
\hline & Subtipe & Beskrywing \\
\hline (1) & Antonomasia & $\begin{array}{l}\text { 'n Eienskap of beskrywing word gebruik } \\
\text { in die plek van 'n persoonsnaam óf 'n } \\
\text { persoonsnaam word metafories op } \\
\text { iemand van toepassing gemaak. }\end{array}$ \\
\hline$(2)$ & Dubbelsinnigheid & $\begin{array}{l}\text { 'n Gedagte of woord kan op verskillende } \\
\text { wyses geïnterpreteer word. }\end{array}$ \\
\hline (3) & Ellips & Die weglating van 'n woord of sinsdeel. \\
\hline$(4)$ & Eufemismes & Stel sake in 'n sagter lig. \\
\hline (5) & Hiperbool & Oordrywing. \\
\hline (6) & Ikonisiteit & $\begin{array}{l}\text { 'n Gelykenis bestaan tussen 'n teken en } \\
\text { die objek waarna die teken verwys. }\end{array}$ \\
\hline$(7)$ & Inkongruensie & 'n Woord in 'n verkeerde konteks gebruik. \\
\hline (8) & Inversie & $\begin{array}{l}\text { Die omkering van woordorde met die doel } \\
\text { om klem te lê op belangrike woorde. }\end{array}$ \\
\hline (9) & Ironie & $\begin{array}{l}\text { 'n Karakter sê een ding, maar bedoel iets } \\
\text { anders, of die figuurlike word letterlik } \\
\text { geïnterpreteer. }\end{array}$ \\
\hline$(10)$ & Kontras & $\begin{array}{l}\text { Ook teenstelling of antitese genoem; } \\
\text { hierdeur word twee dinge direk na } \\
\text { mekaar geplaas om die verskil uit te lig. }\end{array}$ \\
\hline$(11)$ & Litotes & $\begin{array}{l}\text { lets word as kleiner of minder belangrik } \\
\text { voorgestel. }\end{array}$ \\
\hline$(12)$ & Metonimia & $\begin{array}{l}\text { Een saak word gebruik om na 'n ander te } \\
\text { verwys waar dié twee sake nóú met } \\
\text { mekaar in verband staan. }\end{array}$ \\
\hline$(13)$ & Neologisme & $\begin{array}{l}\text { Die skep van 'n nuwe woord, maar } \\
\text { anders as by woordspeling kan die } \\
\text { oorsprong van die woord nie vasgestel } \\
\text { word nie. Die woord word meestal } \\
\text { spesiaal geskep vir die spesifieke } \\
\text { omstandighede. }\end{array}$ \\
\hline
\end{tabular}




\begin{tabular}{|c|c|c|}
\hline (14) & Oksimoron & $\begin{array}{l}\text { 'n Retoriese figuur waarin twee teen- } \\
\text { strydige gedagtes tot een begrip } \\
\text { saamgevoeg word. }\end{array}$ \\
\hline (15) & Onomatopee & Klanknabootsing. \\
\hline (16) & Paradoks & $\begin{array}{l}\text { 'n Skynbare teenstelling wat 'n mate van } \\
\text { inkongruensie bevat. }\end{array}$ \\
\hline (17) & Personifikasie & $\begin{array}{l}\text { Dit ontstaan wanneer menslike eien- } \\
\text { skappe aan die natuur of 'n lewelose } \\
\text { voorwerp toegeskryf word, of wanneer dit } \\
\text { totaal vermenslik word. }\end{array}$ \\
\hline (18) & Repetisie & $\begin{array}{l}\text { Herhaling van woorde wat klem lê op 'n } \\
\text { gedagte. }\end{array}$ \\
\hline (19) & Sinekdogee & $\begin{array}{l}\text { 'n Gedeelte van 'n geheel word gebruik } \\
\text { om na die geheel te verwys. Dié gedeelte } \\
\text { is gewoonlik die belangrikste of ken- } \\
\text { merkendste van die geheel. }\end{array}$ \\
\hline (20) & Sinestesie & $\begin{array}{l}\text { Dit is die tegelyktydige betrek van } \\
\text { verskillende sintuie. }\end{array}$ \\
\hline (21) & Spottery & $\begin{array}{l}\text { Dit sluit die stylfiguur satire en sarkasme } \\
\text { in. }\end{array}$ \\
\hline (22) & Taboeverbreking & $\begin{array}{l}\text { Dit is die gebruik van woorde op so 'n } \\
\text { manier dat dit onbetaamlik is, byvoor- } \\
\text { beeld vloekwoorde. }\end{array}$ \\
\hline$(23)$ & Vergelyking & Twee sake word met mekaar vergelyk. \\
\hline (24) & Klankmanipulasie & $\begin{array}{l}\text { Dit is klank soos dit op papier herken kan } \\
\text { word, byvoorbeeld in alliterasie en } \\
\text { assonansie. Verder kan woorde ook } \\
\text { geskryf/gespel word soos dit foneties } \\
\text { uitgespreek word, byvoorbeeld die woord } \\
\text { in sy ont- of oorgeronde vorm. }\end{array}$ \\
\hline (25) & Woordspeling & $\begin{array}{l}\text { 'n Woord word tot 'n nuwe woord herskep } \\
\text { om by die situasie te pas, maar die } \\
\text { oorspronklike woord kan steeds herken } \\
\text { word. }\end{array}$ \\
\hline
\end{tabular}




\subsection{Humor gesetel in tipografie en illustrasies}

Dit is moontlik, veral in kinderliteratuur, dat humor nie alleen gesetel is in die (kumulatiewe) betekenis van die woorde in die teks nie, maar ook in die visuele. Humor kan voorkom in die tipografie van die woorde op papier, asook in die illustrasies - op 'n verskeidenheid wyses kan bygedra word tot die humoristiese atmosfeer in verhale (Glazer \& Williams III, 1979:340). Die fisiese voorkoms van 'n karakter of die visuele voorstelling van 'n situasie kan bydra tot situasieen woordhumor in die teks.

\subsection{Die geïntegreerde model}

Wanneer humor in 'n verhaal (enige teks vir enige ouderdomsgroep) bestudeer word, kan die humormodel gebruik word en ondersoek ingestel word na die verskillende soorte situasiehumor, die soorte woordhumor en die humor in die tipografie en illustrasies. Wanneer die ontwikkelingpsigologie ook hierby betrek word, kan vasgestel word wat die moontlike reaksies van lesers van 'n bepaalde ouderdomsgroep op die teks kan wees.

\section{Die toepas van die model as teoretiese hulpmiddel}

Ter illustrasie van die model gaan een situasie en enkele woordhumormomente uit elk van drie Afrikaanse kinderverhale bespreek word. Wat situasiehumor betref, word gefokus op slegs een situasie in elke verhaal. Die doel is nie om 'n volledige bespreking van die humor in elke verhaal te gee nie, maar om aan te toon hoe die humormodel toegepas kan word. Verder word kernagtig aangedui hoe die humor in elke verhaal in die tersiêre en intermediêre fases gefasiliteer kan word.

\section{1 'n Haas moet doen wat'n haas moet doen (Martie Preller, 1997)}

\subsubsection{Situasiehumor}

'n Haas moet doen wat 'n haas moet doen (Martie Preller) vertel die verhaal van 'n jong meisie wat verander word in ' $n$ haas en vrede moet bewerkstellig tussen mens en dier. Die verhaal speel af in 'n Afrika-ruimte en dit gaan om ekologiese kwessies - natuurbewaring - te verander op die bevatlikheidsvlak van die middelkinderjare.

Gerda word verander van 'n realistiese tot 'n fantasiekarakter, 'n haas. Wanneer sy bewus word van die verandering, word haar reaksie op 'n realistiese wyse aangebied. Die eerste humortipe wat 
in hierdie situasie voorkom, is verrassing; die leser word eers bekend gestel aan Gerda wat "'n doodgewone kind" (p. 7) is en wat verwag dat alles "net soos ... elke weeksoggend" (p. 8) sal wees. Sy word egter ontnugter toe sy "skielik" (p. 7) nie meer werklik sý is nie. Sy toon vreemde gedrag, soos die behoefte om met haar pootjies onder die duvet te wil grawe (p. 8). Die leser verken saam met Gerda hierdie vreemdheid. Veral die fokalisasie (die verhaalwêreld soos gesien en beleef uit Gerda se oogpunt), karakter-, tyd- en ruimtebeelding is dominant in die beskrywing van hierdie humoristiese situasie.

Sy word progressief meer bewus van die veranderinge wat plaasgevind het. Sy is nou 'n haas, en dit word weerspieël in haar voorkoms en handelinge. Haar verandering van gedaante ('n "haaslyf", "haaspootjies" en "haasbene" - p. 8-9) het ander handelinge tot gevolg as waaraan sy gewoond is: sy wil met haar pootjies grawe (p. 8), sy moet spring (p. 9) en haar gehoor is skerper as voorheen (p. 10). Haar gedagtehandeling korreleer enersyds met dié van 'n mens en andersyds met dié van 'n haas. As mens is sy verbysterd oor die verandering en wonder wat vir haar voorlê. Sy wil byna ontken wat aan die gang is: "Dit kan nie wees nie ... Dit moet 'n droom wees. Dit kan nie waar wees nie" (p. 8-9). Verder begin sy dadelik dink aan die implikasies van die verandering: "Maar wat gaan haar ma sê ..." (p. 10). Tydens hierdie situasie ontstaan 'n humoristiese penarie wat veral betrekking het op karakterisering en gebeure. Humoristiese verrassing word deur die fokalisasie bewerkstellig. Die leser in die middelkinderjare het reeds die vermoë om te kan onderskei tussen realisme en fantasie en sal waarskynlik nie die fantasiegebeure goedsmoeds glo nie: hy/sy behoort Gerda se ongeloof te verstaan en te deel.

Wanneer Gerda haarself eindelik in die spieël sien, skyn dit asof haar groot krisis vergete is: sy bewonder haarself. Die humortipe vergelyking is gesetel in die fokalisasie. Uit 'n gestereotipeerde oogpunt sal dit voorkom asof Gerda tipiese ydel, vroulike gedrag toon (vergelyk ook die karakteriseringstegniek dat Tandjies, die bobbejaan, by twee geleenthede neerhalend na haar verwys as die "wyfiehaas" - p. 34-35). Uit 'n ontwikkelingspsigologiese hoek mag dit eie aan die byna-tiener wees om gesteld te wees op haar voorkoms - veral aangesien sy voorheen "'n doodgewone kind" (p. 7) was. Vir haar selfkonsep as haas is dit positief: haar ingesteldheid teenoor haar nuwe syn is positief, en dit stel 'n hoopvolle vooruitsig vir die afloop van die verhaal. 


\subsubsection{Woordhumor}

Wanneer Gerda en Kerneels, Gerda-hulle se hond, mekaar ontmoet (p. 10-11), is die gebruik van onomatopee en personifikasie humoristies. Die verbale handeling tussen die diere dra by tot die humor deur middel van onomatopee: “'Aha,' grom Kerneels ... 'Gerda,' blaf hy" (p. 10-11). ("Blaf" word in die situasie 'n verdere vyf keer op dié spesifieke manier gebruik.) Dié onomatopee is verder humoristies wanneer Kerneels dit as werkwoord gebruik: “... en terwyl jy nou kan verstaan wat ek blaf, wil ek sommer vir jou blaf dat daardie korrels wat julle my voer oneetbaar droog en onsmaaklik is" (p. 11). Die personifiëring van Kerneels word verder humoristies: hy "glimlag" (p. 11) wanneer hy besef dat Gerda hom kan verstaan en verwyt Gerda as sy nie dadelik begrip toon daarvoor dat hy nie meer die droë hondekorrels kan eet nie (p. 11).

Afhangende van die lesers se werklikheidsbeskouing en belewing van die wêreld waarbinne hulle hulle bevind, kan die samevoeging van strydende gedagtes humor tot gevolg hê. Gerda verwys na Andries en Yvonne as "baie ordentlike aasvoëls" (p. 30). Dit kan beskou word as 'n oksimoron, want aasvoëls word normaalweg eerder beskou as asend op ander. Die humor ontstaan dus deur die oorsteek van die grens tussen 'n realistiese wêreld en 'n fantasiewêreld.

\subsubsection{Moontlikhede vir fasilitering}

In tersiêre onderrig word die hele verhaal gelees en die humoristiese situasies uitgesoek, waarna die riglyne in die humormodel gevolg kan word om te bepaal watter soorte humor in 'n situasie of toneel voorkom - is dit veral geleë in die karakterisering, die gebeure, die ruimte, die tyd, of 'n kombinasie van verskillende verhaalaspekte? Verder kan die hele teks nagegaan word vir woordhumor, sodat die subtipes daarvolgens vasgestel kan word. As 'n mens wetenskaplik nagaan waarom iets humoristies is, is die voorbeeld gewoonlik nie meer so lagwekkend nie, maar die wins daarvan is daarin geleë dat die ondersoeker die werking van taal, en die effek en krag daarvan beter verstaan en - vanuit 'n posisie van kennis en kundigheid daarvolgens benaderingswyses en strategieë sal ontwikkel om die verskeidenheid aspekte van die humormodel op die vlak van die kind, in hierdie geval die intermediêre fase, aan te pas. Dit beteken dat die taalfasiliteerder heelwat kennis, vernuf en 'n voortdurende ingesteldheid op kreatiwiteit moet hê. 
Wanneer 'n verhaal, ook 'n verhaal waarin humor voorkom, vir leerders in die intermediêre fase gefasiliteer word, is dit noodsaaklik om genoeg tyd in te ruim vir die geleidelike invoeling in die stemming van 'n verhaal. Dit werk gewoonlik teenproduktief om 'n verhaal oorsigtelik te bespreek en hier en daar ' $n$ voorbeeld van humor te probeer uitwys - die verhaal moet beleef word; daar moet genoeg tyd wees om die hele verhaal, of groot gedeeltes daarvan, saam in die klas te lees, sodat die verhaal eers (saam) geniet kan word en daarna bespreek kan word; dit kan 'n positiewe effek hê op die ontwikkel van langtermynleesgewoontes. Groepwerk, projekwerk en portuur-/maatassessering is prominent in die intermediêre fase, en daarvoor is daar ruim geleentheid in die saamlees van ' $n$ Haas moet doen wat 'n haas moet doen.

Sommige kenmerke van leerders in die intermediêre fase, wat van toepassing is op die gebruik van humor in 'n Haas moet doen wat 'n haas moet doen, is die volgende (vergelyk in hierdie verband Louw, Van Ede \& Louw, 1998:354-376 ten opsigte van die sosiale ontwikkeling van die kind in die middelkinderjare). Kinders van hierdie ouderdom raak meer sensitief oor hoe hulle optrede ander affekteer (vergelyk Gerda en die mense se optrede teenoor diere); hulle begin ander se behoeftes, begeertes en standpunte in ag neem ('n situasie ontwikkel waarin die mense die lot van die diere moet aanhoor). Ook begin hulle groeptake makliker koöperatief doen (verskillende fasette van natuurbewaring - soos wat dit uit die verhaal na vore kom, kan deur verskillende groepe bespreek word). Verder begin hulle die uitdaging geniet om take onafhanklik af te handel (Gerda het as individu die taak op haar moes neem om na die diere toe te gaan). Die onderrigkonteks sluit ook veeltaligheid, menseregtekwessies en omgewingsopvoeding in, wat deurgaans in humoristiese situasies en woordhumor in 'n Haas moet doen wat ' $n$ haas moet doen betrek kan word. Dit is belangrik om in gedagte te hou dat humor dikwels funksioneer as 'n meganisme vir die bespreek van ernstige probleme van velerlei aard.

Louw et al. (1998:330-348) se uiteensetting van die kognitiewe ontwikkeling van ' $n$ kind in die middelkinderjare, in casu die leerder in die intermediêre fase, toon die volgende trekke: leerders het die begeerte om beheer oor hul eie leerproses te neem (dit word uitgebeeld in Gerda se selfstandige benadering van die probleem van die benadeling van die diereryk). Kinders in dié leeftydfase raak meer doelgerig en metodies in hul benadering (alhoewel daar heelwat verrassings was vir Gerda, kon sy inderdaad ook beplan om probleme te help oplos). Ook raak hulle toenemend in staat om 
inligting te verkry, op te teken en te manipuleer (Gerda se hele feitesending, optrede en positiewe bydrae tot die beter begrip tussen die mense en die diere berus daarop). In hierdie ontwikkelngstadium is kinders toenemend in staat om inligting te ondersoek, te vergelyk en krities te beoordeel (soos Gerda, sal ook die leerders die verhaalinligting kan ondersoek en krities beoordeel). Leerders kan uiteindelik ook 'n kombinasie of reeks situasies kies en 'n toneeltjie opvoer.

Een van die belangrikste kritieke uitkomste, naamlik die openbaar van verantwoordelikheid teenoor die omgewing en die welstand van ander, kan uitstekend aan die hand van hierdie verhaal gefasiliteer word; in hierdie verband is Louw et al. (1998:330-383) se bevindinge oor die verband tussen die kogitiewe, sosiale en morele ontwikkeling van ' $n$ kind in die middelkinderjare insiggewend. Leerders kan aan die hand van hierdie verhaal tot 'n beter begrip kom van 'n ander belangrike kritieke uitkoms, naamlik dat die wêreld as 'n stel verbandhoudende stelsels bestaan - in hierdie verhaal die verband tussen die diereryk, die menslike samelewing en die rol van die politiek daarin. Sodoende kan hulle insien dat die suksesvolle oplos van probleme dikwels nie in isolasie bestaan nie, maar juis gesetel is in die samewerking van verskillende belanghebbendes vanuit verskillende kontekste.

Een van die addisionele uitkomste wat ook deur middel van hierdie verhaal gefasiliteer kan word, is die individu as 'n verantwoordelike burger se deelname aan die plaaslike, nasionale en internasionale gemeenskapslewe. Hiervan is Gerda as hoofkarakter 'n uitnemende voorbeeld, en die humor, fantasie en avontuur dra daartoe by dat 'n ernstige en gewigtige kwessie op 'n speelse en humoristiese wyse oorgedra word.

Enkele van die uitkomste wat spesifiek vir tale in die intermediêre fase gestel word, is dat die leerders die wyses beskryf waarop 'n teks, in hierdie geval hierdie verhaal, hul emosionele reaksie beïnvloed het (soos: metafoor, ritme, figuurlike taal, alliterasie - hiervan is daar heelwat voorbeelde in die humor in 'n Haas moet doen wat 'n haas moet doen.) Sodanige beskrywing behels dat die kind/leerder se kognitiewe ontwikkeling ter sprake kom, omdat hy verstandelik met die teks moet omgaan (vergelyk in hierdie verband Louw et al., 1998:330-348). Verder moet leerders in hierdie fase, en spesifiek in Graad 6, die intrige, ruimte, karakters en atmosfeer op 'n dieper vlak kan ontleed; aan die hand van geselekteerde voorbeelde van situasiehumor kan dit die leeservaring vir leerders veraangenaam. Hulle kan die gevolge van Gerda se handelinge probeer voorspel 
asook hoe gebeurtenisse in die verhaal gaan eindig. Hulle moet ook verstaan wat karakters motiveer, maar handelinge kan bevraagteken waar nodig en hulle menings kan regverdig; hiervoor kan verskeie van die karakters met wie Gerda in aanraking kom, as voorbeelde gebruik word. Die herken en bevraagtekening van partydigheid en stereotipering kan in verskeie situasies op verskeie karakters, byvoorbeeld die aasvoëls, van toepassing gemaak word. 'n Volgende leeruitkoms, naamlik om krities na te dink oor die tema van die verhaal - dat elkeen 'n verantwoordelikheid het om na te kom en dat niemand ooit gering geag moet word hierin nie - en dat kwessies met die leerder se eie lewe in verband gebring moet word, word deur die humor in die verhaal op die vlak van die middelkinderjare makliker en aangenamer aangebied.

\subsection{Aliens en engele (Leon de Villiers, 1996)}

\subsubsection{Situasiehumor}

Nog 'n kinderverhaal wat besonder geskik is vir die betrek van humor in die onderrigsituasie op tersiêre en op intermediêre vlak, is Leon de Villiers se Aliens en engele (1996).

Pieter is ' $n$ jong seun wie se ouers geskei is. Hy woon by sy ma en sy grootste droom is dat sy ouers weer sal saam wees. Die verhaal beskryf die proses waardeur Pieter moet gaan om sy ouers se egskeiding te verwerk. Deurgaans werk sy verbeelding teen hoogste versnelling en sien hy alles om hom in terme van planete, ruimtereise en aliens.

Wanneer Pieter se pa hom een naweek kom haal om by hom te gaan kuier, kom Pieter agter dat sy pa hom wil voorstel aan iemand. Wanneer Pieter die nuwe mense ontmoet, is sy handeling, veral gedagtehandeling, humoristies. Hoewel hulle baie vriendelik met hom is, is hy terughoudend, selfs tot op 'n vlak waar dit humoristies verrassend is. Daar is ook 'n mate van humoristiese herkenning in hierdie situasie.

Die eerste persoon wat hy ontmoet, is die Strik, oftewel Anja. Sy is die dogter van sy pa se vriendin. Pieter gee aan haar in sy gedagtes hierdie bynaam na aanleiding van die rooi strik in haar hare. Verder stereotipeer hy haar in sy gedagtes:

Die Strik bekyk hom op en af en roer haar lippe asof sy wil glimlag. Pieter verroer nie ' $n$ spier nie. 'n Mens kan nooit te versigtig vir 'n strikmeisiekind wees nie (p. 33). 
Louise, Anja se ma, probeer vriendelik met Pieter wees en merk op dat sy pa vir haar al baie van hom vertel het:

Sy pa moet gejok het, want hy weet nie veel van hom af nie. Toe hy en sy pa en sy ma nog in hulle ou huis gebly het en sy pa elke dag met hom gespeel het, het hy dalk geweet, maar nie nou meer nie (p. 34).

Hoewel hierdie situasie beskou kan word as humoristies verrassend en kontraswerkend van aard, is Pieter se reaksie 'n simptoom daarvan dat hy nog nie sy ouers se egskeiding verstaan of verwerk het nie. Die humor dra daartoe by dat hierdie simptome op 'n ligter manier gemedieer word: Pieter se probleme word nie by die naam genoem nie, maar is identifiseerbaar. Die humor word veral gevind in die karakterisering.

Pieter het vooroordele teenoor Anja, veral ten opsigte van haar rol in die ruimtestasie. In Pieter se verbeeldingswêreld is die Strik eintlik ' $n$ bemanningslid wat in die ruimtestasie op haar pos moet wees. Volgens hom is sy nie goed opgelei nie, want sy bly in die geselskap sit in plaas daarvan om terug te keer na haar pos. Dit laat hom besluit dat, hoewel dié mense in 'n ruimtestasie woon, hulle dit nie behoorlik kan bestuur nie. Dit is ironies (ten opsigte van karakterisering), want die Strik is juis beleefd deur in die geselskap te sit.

Hy maak ook die afleiding dat die gasvrou en haar dogter so vreemd reageer omdat hulle aan 'n ruimtesiekte ly, en voortaan bring hy hulle gedrag in verband hiermee. Volgens hom word Anja ernstig deur die ruimtesiekte beïnvloed:

Hierdie Strik knaag vir seker aan die stoele en tafels as niemand kyk nie. Dis wat gebeur as 'n mens ruimtekoors kry (p. 35).

In hierdie situasie word die afmetings van Pieter se verbeeldingswêreld humoristies verrassend aangedui. Oordrywing kom veral voor in die ruimtebeelding en karakterisering. Hoewel die leser hierdie verbeeldingswêreld al 'n bietjie leer ken het, kan Pieter se optrede nie voorsien word nie, veral omdat dit so oorspronklik is. Dit is ook duidelik dat hierdie ruimte en mense vir Pieter heeltemal verander en van gedaante verander sodat dit in sy verbeeldingswêreld kan pas.

Louise het hoendervleis voorberei vir aandete en wil weet of Pieter dit eet. Hoewel sy pa oortuig is dat hy enigiets eet, voer Pieter aan dat hy nie Marshoenders eet nie. Dit bring die ander karakters in die war, en dan ontstaan daar humoristiese misverstand, gesetel in 
karakterisering. Louise wil weet wát presies Marshoenders is: "Is dit hoenders wat oor lang afstande aangejaag word of iets?" (p. 36). Toe sy pa vra of sy ma soms vir hulle Marshoenders gaarmaak, maak dít weer nie vir Pieter sin nie, aangesien hy en sy ma op Neptunus woon.

$\mathrm{Na}$ ete stel die Pêrelvrou (Anja se ma) voor dat hy skaak teen Anja moet speel. Hy is nie lus om skaak te speel teen iemand wat volgens hom ruimtekoors onder lede het nie en geniet die spel inderdaad nie. Humoristiese verrassing, asook inkongruensie, kom voor in die fokalisasie en die karakterisering:

Wat is nou lekker daaraan as die perd, wat sy 'n ruiter noem, elke keer op presies dieselfde manier moet beweeg? Geen ordentlike perd sal dit mos doen nie.

Die Strik wil ook nie dat hulle verder speel nadat sy sy koning skaakmat gesit het nie. Pieter gluur haar aan. Definitief ruimtekoors! (p. 37-38).

Pieter kan homself en sy optrede nie objektief beskou nie - dit bemoeilik sy interaksie met die ander karakters. Verder beïnvloed dit ook sy siening van die ander karakters negatief. Veral lesers wat vertroud is met skaak, mag hierdie situasie humoristies vind.

\subsubsection{Woordhumor}

Téén sy ma se opdrag in gaan loop Pieter buite rond en beland in 'n straat waar daar veral woonstelle is. Daar is egter ook 'n paar "bang" ou huise; Pieter gebruik die neologisme, "bolwangstoep" (p. 7) in sy beskrywing van een van die huise, en dit is 'n voorbeeld van fyn humor, veral vanweë die visuele beeld wat daaraan gekoppel kan word.

Onderweg huis toe is Pieter in 'n hysbak saam met 'n man wat rook en Pieter vermoed dat hy van Jupiter is. Pieter oordryf wanneer hy wonder of "daar 'n hele nuwe kolonie aliens op Jupiter" (p. 14) is. Dit is nie ongewoon om humoristiese hiperbool in 'n verhaal te kry waar die hoofkarakter, wat boonop fokaliseerder is, ongeveer tussen nege en twaalf jaar is nie.

Wanneer Pieter agterkom dat Nebiekatneser sy pa se vriendin se tuin verwoes het, besef hy dat hulle in groot moeilikheid is. Sy reaksie, "O borrels! O blêrrie borrels!" (p. 46), is humoristiese taboeverbreking (blêddie is afgelei van die Engelse woord "bloody"), asook klankmanipulasie in die vorm van alliterasie. Die gebruik van 
die taboewoord dui op die intensiteit van Pieter se penarie en moontlik ook op sy skuldgevoel.

\subsubsection{Moontlikhede vir fasilitering}

In tersiêre onderrig kan die leser die verband tussen die literatuurteorie, die ontwikkelingpsigologie en spesifiek humor en verbeeldingskrag ondersoek. Dit kan dan gekombineer word met ekokritiek, wat impliseer dat tersiêre leerders ook toegerus moet word met kennis van literatuurteorieë oor omgewingsbewaring wat hulle dan weer op die vlak van die leerder in die intermediêre fase kan aanpas. $^{2}$

Onderwerpe wat spesifiek by die leerders in die intermediêre fase se individuele behoeftes en verwagtinge aansluit, asook by dié van die individu binne die konteks van die groter gemeenskap, behels byvoorbeeld maatskaplike kwessies soos Pieter as eenkantkind wat voel dat hy nie vir ander bestaan nie, dat hy "onsigbaar" is vir volwassenes, omdat hulle hulle glad nie aan hom steur nie. Daar kan nagegaan word op watter wyses die humor in die verhaal eufemisties gebruik word om moeilike omstandighede te oorkom.

In hierdie verhaal word besondere klem geplaas op verskillende soorte verhoudings en die karakters word deur die hoofkarakter, Pieter, gegroepeer as aliens en engele. Deur 'n aantal humoristiese situasies in die verhaal te selekteer, kan leerders besluit wat die negatiewe en wat die positiewe eienskappe van karakters is. Hulle moet ook die oorsaak van die probleme in Pieter se lewe probeer identifiseer, vasstel op watter wyse die outeur oplossings daarvoor probeer vind het in die verhaal, en dan self tot besluite en oplossings vir probleme probeer kom, deur krities en kreatief te dink.

Juis omdat dit in die verhaal gaan om Pieter wat 'n soort eenkantkind is, behoort van groepwerk gebruik gemaak te word in die fasilitering van die verhaal, sodat daarmee gedemonstreer kan word dat kinders/die samelewing mense nie moet uitstoot bloot op grond daarvan dat hulle 'n ryk verbeeldingskrag het nie. Sensitiwiteit vir sosiale kontekste, as een van die addisionele uitkomste, kan aan die hand van die humor in hierdie verhaal gefasiliteer word (vergelyk in hierdie verband Louw et al., 1998:354-376).

$2 \quad$ Vergelyk in dié verband Marais (1990) se inleiding tot die bundel Groen, asook Marais en Zuiderent (1997) se beskouinge oor die verhouding tussen die omgewing en die letterkunde in Ons klein en silwerige planeet. 
Soos in die fasilitering van die vorige verhaal, kan ook Aliens en engele in die intermediêre fase vanuit die hoek van situasiehumor benader word wat betref karakterontleding, die gebeure, die ruimte, die tyd en die atmosfeer. Wat besonder opvallend is in hierdie verhaal, is die klem op verbeeldingskrag - dit kan verder ontgin word ten opsigte van die verband tussen humor, verbeeldingskrag en kreatiewe taalgebruik.

\subsection{Vincent van Gogga (Philip de Vos, 1990)}

\subsubsection{Situasiehumor}

Die laaste verhaal wat as voorbeeld dien van die aard en fasilitering van aspekte van humor in kinderverhale, is Vincent van Gogga (1990) deur Philip de Vos.

Vincent van Gogga vertel die verhaal van 'n vlooi in sy laattienerjare wat die huis verlaat om sy eie lewe te bou. In sy omswerwinge leer hy baie van die lewe en maak vriende met 'n ander vlooi wat hom help om sy skildertalent te ontwikkel.

Vincent van Gogga en sy vriend, Paul Ghôghaa, kyk toe terwyl madame Zelda, ' $n$ skelm fortuinverteller, vir Magdalena Aggenbag, 'n kinderboekskrywer, verkul. Net voordat Magdalena dan 'n kosbare hangertjie aan madame Zelda kan toevertrou, besluit Paul om in te gryp. Hier word humoristiese verwagtings geskep, want madame Zelda mag dalk groot skrik as sy dié twee goggas in die kristalbal sien. Hulle besluit egter om eers een van Vincent se skilderye teen die kristalbal te druk:

Madame Zelda ... tuur in die kristalbal en begin praat: 'Die man se naam is ...'

Maar voordat sy die naam kan sê, druk die twee vlooie Vincent van Gogga se prent teen die kristalbal vas.

'Jesaja!' skreeu madame Zelda en sy deins verskrik terug.

'Jesaja?' sê Magdalena.

'Nee, sy naam is nie Jesaja nie ... hy het nie 'n naam nie ... ek bedoel ek sien g'n naam nie,' brabbel madame Zelda deurmekaar. 'Ek sien 'n yslike koringland. Daar is donker wolke in die lug en dit lyk asof daar ' $n$ vreeslike storm aan die broei is. En die hele wêreld is die ene pikswart kraaie! Ag, Jesaja en Jeremia! Wat sou dit alles beteken?'

'Vergeet van die kraaie,' sê Magdalena. 'Sê eerder vir my wat is die nare, aantreklike man se naam.' 
'Gou!' sê Paul Ghôghaa. 'Druk jou gesig styf teen die kristalbal vas!' (p. 42).

Dít wat madame Zelda in die kristalbal sien, is 'n verhaalmatige verwysing na een van Van Gogh se bekende skilderye, "Koringland met kraaie". Die medieerder kan dus ter vergelyking vir die jong leser die illustrasie op p. 30 en 'n afdruk/prent van die werklike skildery wys. Op hierdie wyse kan die karakter nader gebring word aan die lewe en werk van die werklike Vincent van Gogh.

'n Humoristiese penarie ontstaan wanneer die vlooie hulle gesigte teen die kristalbal druk. Madame Zelda gebruik 'n afstandbeheerde kassetspeler wat sy binne 'n opgestopte Isis-likkewaan versteek om haar kliënte te verkul. Wanneer sy dan die twee vlooie deur die kristalbal sien, skrik sy so groot dat sy verbouereerd begin om die kontroledosie se knoppies te druk om tyd te wen. Skielik druk sy al die knoppies gelyk, en die uitwerking daarvan is dat die opgestopte Isis-likkewaan se beloftes meer buitengewoon raak as voorheen:

'Jy gaan 50000 mans in 'n kompetisie wen!'

'Jou oupa in Mauritius gaan volgende jaar oorsee met 'n lang, donker, aantreklike man!' (p. 43).

Hierdie beloftes behels humoristiese ironie, gewelddadigheid en taboeverbreking, omdat madame Zelda se plan hoegenaamd nie uitwerk nie, sy die slagoffer word van geweld wat sy self indirek veroorsaak het, en omdat die lesers hulle waarskynlik verkneukel in madame Zelda se penarie. Wanneer die likkewaan neerstort, mis dit Magdalena met sentimeters, maar tref madame Zelda. Die gebeure is ' $n$ duidelike voorbeeld van humoristiese klugtigheid. Toe alles rustiger is, waag Magdalena dit om te verneem na madame Zelda se welsyn. Magdalena formuleer haar vraag dramaties, wat oordrywing tot gevolg het: "Madame Zelda, sê vir my, lewe u nog of het u dalk die tydelike met die ewige verwissel?" (p. 45). Die humor in die situasie is gesetel in die karakterisering, die gebeurebeelding asook die ruimtebeelding.

Voordat Magdalena hulp kan inroep, kom madame Zelda by. Sy reageer heeltemal anders as voorheen: haar identiteitsverwisseling lei tot haar ontmaskering:

Skielik onthou Magdalena van iets. 'Madame Zelda,' sê sy, 'sê tog asseblief nou vir my wat is die lang, donker man se naam?'

'Naam?' vra madame Zelda. 'Bettie Potgieter, natuurlik!' 
'Bettie Potgieter?' vra Magdalena. Dis darem 'n eienaardige naam vir 'n aantreklike man!'

'n Man?' vra madame Zelda, en nou is dit sy wat dronkgeslaan is. 'Dis my naam,' sê sy.

Magdalena is nou nog deurmekaarder. 'Maar is u nie madame Zelda die Egiptiese fortuinvertelster nie?'

'Nee, kindjie,' sê die vrou op die vloer. 'My naam is Bettie Potgieter - gebore en getoë in Boksburg. Madame Zelda se dae is ewig en altyd verby!' (p. 45-46).

Inkongruensie, ironie, verrassing en misverstand kom voor in die gebeure- en karakterbeelding. Die naïewe Magdalena word 'n teiken van die verteller se spot. Die humor is gesetel in die karakterisering en die gebeurebeelding. 'n Leser ervaar waarskynlik 'n mate van indirekte bevestiging: hy/sy het waarskynlik so iets verwag vanweë sy/haar insig in die karakters en hulle omstandighede. As gevolg van die feit dat 'n leser met sekere karakters kan identifiseer en hom-/haarself van ander karakters kan distansieer in die literatuur, is hier 'n sterk moontlikheid dat 'n leser 'n gevoel van vervreemding teenoor sekere karakters, veral madame Zelda, kan ervaar, en daarom ook 'n distansiëring van sekere negatiewe waardes.

\subsubsection{Woordhumor}

In plaas daarvan om die woud "gevaarlik" te noem, gebruik die verteller woordspeling in die vorm van die woord "gevaarvol" (p. 11). In die gevaarvolle woud is daar ook vreemde verskynsels. Die tande van 'n kam of borsel is Swart Monsters, terwyl daar Vreeslike Vloedwaters kom wanneer madame Zelda haar hare was. Wanneer sy dan haar hare droogblaas, tref die Skroeiwarm Stormwind die vlooie. Madame Zelda ly ook aan skilfers - in vlooitaal Wit Vlokke. Hoewel dit dinge is wat die leser dadelik sal herken, is dit vir vlooie onbekend, en dus is die humoristiese naamgewing, wat beskryf kan word as sinekdogee, baie toepaslik (p. 11-12). Die benamings word beskou as sinekdogee, omdat dit slegs 'n gedeelte van 'n groter geheel benoem, maar vanuit die vlooie se beperkte belewenishoek is slegs die gedeeltes benoem.

Die verafrikaansde spelling van die woord "gypsy", "djipsie" (p. 18 en 22), verteenwoordig humoristiese klankmanipulasie wat afgelei is van die uitspraak van die woord. Die ironie is daarin gesetel dat madame Zelda, wat juis grootdoenerig is, bloot 'n "djipsie" genoem 
word. Die klankmanipulasie neig na 'n taaldegradering wat geringskatting suggereer.

Wanneer Mitsi madame Zelda besoek, word vertel dat madame Zelda die fluweeldoek met haar "lang vingers" van die kristalbal lig (p. 23). Hierdie beskrywing kan dubbelsinnig geïnterpreteer word, en in madame Zelda se geval is dit ironies, aangesien die letterlike en figuurlike beskrywings ooreenstem.

Mevrou Blanche Terblanche lê ook besoek af by madame Zelda. Haar man is die Minister van Konfusie (p. 27), en in die plasing van "Minister" en "Konfusie" in een konstruk kan woordironie en inkongruensie geïdentifiseer word, aangesien die woord konfusie geïnterpreteer kan word as verwarring. Die minister het dié naam gekry vanweë sy ontsteltenis oor die politieke praktyke wat in daardie tyd aan bewind was. Terselfdertyd verwys dit na die Sjinese filosoof Confucius wat ongeveer 500 jaar voor Christus geleef het.

Wanneer Vincent vir Paul ontmoet, stel Paul homself voor as Ghôghaa, wat verwys na die Franse skilder Gauguin, maar dit sinspeel ook op sy gogga-agtige aard. Daar is ligte spot met Paul se effense grootdoenerigheid in sy interaksie met Vincent.

Die Van Gogga-gesin is baie in hul skik met Vincent se werk. Tog is dit ironies dat Theo daarvan praat as "prente" en die woordspeling, "skilferye" (p. 51), wat Paul gebruik, is ook humoristies. Deur middel van hierdie ironie en woordspeling word die belangrike funksie van die skilderkuns in die verhaal beklemtoon.

\subsubsection{Moontlikhede vir fasilitering}

In tersiêre onderrig kan humor so gedetailleerd moontlik aan die hand van die model ondersoek word, maar dié belangrike vraag ook bespreek word: laat die humoristiese aard van hierdie verhaal reg geskied aan die lyding in Vincent van Gogh se lewe? Tersiêre leerders kan gelei word om te begryp dat dit daarom gaan dat dit 'n kinderverhaal is, geskryf vir kinders as teikengroep, en dat humor 'n baie goeie alternatiewe medium is om jong lesers geïnteresseerd te kry in so 'n omvangryke studieveld soos die skone kunste en die lewe en werk van Vincent van Gogh. Goeie bronne oor Vincent van Gogh is onontbeerlik vir die fasilitering van hierdie verhaal in sowel die tersiêre as die intermediêre fase; bronne wat oorweeg kan word, is byvoorbeeld Van Gogh: alle schilderijen (Walther \& Metzger, 2001) en 'n omvangryke keuse uit die briefwisseling tussen Vincent 
en sy broer Theo: Vincent van Gogh: een leven in brieven (Hulsker, 1998).

Vir fasilitering in die intermediêre fase kan 'n aantal humoristiese situasies ontleed word, sodat leerders verbande tussen die karakters, die gebeure en die ruimte en die soorte situasiehumor kan insien. Aan die hand van die humoristiese wyse waarop die samewerking tussen die verhaalkarakters Vincent van Gogga en sy vriend, Paul Ghôghaa uitgebeeld word om madame Zelda te uitoorlê, kan die volgende aspekte bespreek word: Wat behels die belangrikheid daarvan dat mense se gedrag sosiaal aanvaarbaar is? Wat is die belangrikheid van samewerking met ander - afhangende van die etiese aanvaarbaarheid daarvan (vgl. ook Louw et al., 1998:354-376)?

Verder is Philip de Vos se taalgebruik altyd tot in die fyn grein afgerond, sodat woordhumor met talle voorbeelde toegelig kan word. Leerders kan aangemoedig word om hulle eie nuutskeppings te maak - woordvondste na aanleiding van humoristiese neologismes of die humoristiese gebruik van idiomatiese uitdrukkings. Grappige vergelykings kan geskep word, gebaseer op ongerymdheid en oordrywing. Die illustrasies dra ook by tot die geestige effek. Leerders kan debatteer oor die geslaagdheid van die ietwat ruwe illustrasiestyl - juis omdat Vincent van Gogh as voorloper van die ekspressionisme ook nie so fyn en subtiel gewerk het soos sy voorgangers, die impressioniste, nie. Die leeruitkoms waarin gestel word dat leerders ook moet lees en kyk vir inligting en krities reageer op die estetiese, kulturele en emosionele waardes in tekste, kan besonder goed in die bestudering van hierdie verhaal gefasiliteer word, onder andere deur die betrek van biografieë en kunsboeke. Dit gaan immers hier om woordkuns, skilderkuns, die Nederlandse, Franse en algemene Europese kunsinvloede en Vincent van Gogh se intense persoonlikheid - wat alles vereenvoudig moet word sodat dit op die bevatlikheidsvlak van die leser in die middelkinderjare kan wees. Leerders wat daarvan sal hou om met tekeninge te reageer op verhale, of om "bykomende" illustrasies vir die gelese boek te maak, kan byvoorbeeld karikature teken, of grappige situasies uit die boek uitbeeld.

Deur die aanraking met hierdie verhaal kan die leser se emosionele groei en insig in sosiale waardes bevorder word - wat verdere leeruitkomste van hierdie fase is. Leerders kan leer om sensitiewe en gebalanseerde terugvoering oor klasmaats se idees en werk te gee, omdat dit daarby aansluit dat Vincent van Gogh in sy eie lewe nie die toegeneentheid van ander ervaar het nie. Terugvoering met 
verwysings na Van Gogh se lewe moet egter met besondere omsigtigheid hanteer word, sodat leerders wat voel dat hulle uitgestotenes is - soms juis omdat hulle hoogs intelligent, individualisties, of vernuwende denkers en doeners is - nie in verdere eensaamheid verval nie, maar juis sosiale vaardighede - onder andere 'n fyn sin vir humor - kan aanleer sodat hulle makliker in die samelewing kan inskakel of opgeneem word.

\section{4 'n Vergelyking van die drie tekste}

Afhangende van die groep aan wie die onderrig gegee word, kan ook ' $n$ vergelykende studie van die drie tekste gedoen word. Dit is deel van die ontwikkeling van die kognitiewe vaardighede op tersiêre vlak dat studente vergelykende navorsing sal kan doen. In die geval van hierdie verhale kan studente die verskille (variante) en ooreenkomste (konstantes) tussen die drie verhale bepaal deur telkens die drie tekste met mekaar te vergelyk ten opsigte van die situasiehumor, die verbale humor en die humor in die tipografie en illustrasies. Dit kan eers kolomsgewys aan die hand van die model gedoen word en daarna beskryf word, om op grond daarvan afleidings te maak oor humor vir die middelkinderjare oor die algemeen.

Vir intermediêre onderrig kan die soorte humor in verhale ook vergelyk word, alhoewel op 'n baie vereenvoudigde wyse. Leerders kan byvoorbeeld humoristiese situasies uit verskillende boeke met mekaar vergelyk, en aandui of die humor eerder op die vlak van situasiehumor lê (in byvoorbeeld die die karaktertekening en gebeure) of eerder in die woordhumor (byvoorbeeld woordskeppings en uitdrukkings).

\subsubsection{Vergelyking ten opsigte van situasiehumor}

'n Vergelyking ten opsigte van die humor in die drie verhale kan vir tersiêre en intermediêre vlakke aangepas word volgens leerders se bevatlikheidsvlakke. Vir leerders in die intermediêre fase sal die model heeltemal vereenvoudig en aangepas word volgens die terminologie wat vir die betrokke graad in die intermediêre fase voorgeskryf word.

Al die situasiehumortipes wat deur die model aangedui is, kom voor in die drie Afrikaanse verhale. Die tipes wat in al drie die verhale voorkom, is herkenning, indirekte bevestiging, inkongruensie, ironie, klugtigheid, misverstand, oordrywing, spottery en verrassing. 
Waar humortipes nie so geredelik geïdentifiseer is nie, beteken dit nie dat dit nie geskik is vir kinderverhale nie. Dit kan wel moontlik beteken dat die wyse waarop die onderwerpe van die verskillende verhale uitgebou is, hulle nie so geredelik tot sekere humortipes leen nie.

\subsubsection{Vergelyking ten opsigte van woordhumor}

In die analises is eksemplaries te werk gegaan. Wanneer 'n humortipe nie in 'n verhaal aangedui is nie, beteken dit nie dat die stylfiguur waarop dit gebaseer is, nie in die verhaal voorkom nie. Dit impliseer wel dat die stylfiguur moontlik nie binne 'n humoristiese konteks voorkom nie. Verder moet ook beklemtoon word dat daar sover moontlik wetenskaplik-objektief met die verhale omgegaan is, maar dat daar steeds vanselfsprekend ' $n$ mate van subjektiwiteit betrokke is by die identifisering van humoristiese situasies of woordmomente.

In al drie die verhale kom inkongruensie, ironie en woordspeling voor. Die afleiding kan dus gemaak word dat ironisering, waarin dit dikwels gaan om die teenoorgestelde van wat verwag word, aansluit by die verrassingsaspekte in ' $n$ verhaal. Woordspeling sluit aan by taal as spel, wat een van die belangrikste kenmerke en funksies van kinderliteratuur is.

\subsubsection{Moontlikhede vir die fasilitering van 'n vergelyking tussen die drie tekste}

Om 'n studie van humor in 'n kinderverhaal te doen, vereis van die tersiêre leerder denkvaardighede soos geheue, insig, analise, toepassing, sintese en evaluering; vergelyk in hierdie verband Bloom se (in opvoedkundekonteks - baie bekende) bemeesteringsleer in byvoorbeeld Woolfolk (1998:332; 481-484) se Educational psychology. Vergelykende studies stel verdere eise aan die wetenskaplike en professionele vaardighede van die tersiêre leerder in byvoorbeeld onderwysersopleiding: uit die vergelyking moet variante en konstantes afgelei word ten opsigte van byvoorbeeld die humor in die drie kinderverhale. So 'n benaderingswyse impliseer dat die tersiêre leerder, wanneer hy/sy self as taalonderwyser humor in kinderverhale vir die intermediêre fase moet fasiliteer, met kreatiewe vindingrykheid kan besluit watter aspekte van twee, verkieslik drie kinderverhale waarin humor voorkom, op watter wyses vergelykend gefasiliteer gaan word. Nina Mikkelsen (2000: 297, 337-343) se besonder bruikbare siening van interdissiplinêre studies en die vergelykende fasilitering van verhalende tekste in Words and 
pictures: lessons in children's literature and literacies, asook die winste van die konstruktiwisme vir die vergelyking van verskillende tekste oor die algemeen, soos uiteengesit deur Nancy Nelson Spivey (1997) in The constructivist metaphor: reading, writing, and the making of meaning, kan oorweeg word.

Hierdie vind van verskille en ooreenkomste tussen verskynsels (in casu die humor in drie gekose kinderverhale) kan 'n mens in alle fases van sy/haar lewe die diversiteit en universaliteit van dinge in die bestaanswerklikheid beter leer begryp. In die geval van die aanraking met en/of bestudeer van humor in kinderliteratuur word dit 'n lewenslange ontwikkel van 'n fyn sin vir humor wat bydra tot die mens se geestesgesondheid oor die algemeen.

\section{Ten slotte}

Dit blyk dus duidelik dat humor ' $n$ belangrike rol in kinderverhale speel. Dit is nie beperk tot sekere onderwerpe nie en kan voorkom in verhale met 'n verskeidenheid onderwerpe. Humor maak die verhaal vir die leser toeganklik: die verhaal word vir die leser 'n leesén leerervaring. Die verskeidenheid humortipes wat in ' $n$ verhaal voorkom, maak dit vir 'n verskeidenheid lesers met verskillende soorte sin vir humor geslaagd. Humor voeg dus waarde toe tot 'n verhaal en kan 'n kragtige instrument wees in die hand van die outeur en medieerder. Die kinderleser kan sensitief gemaak word vir humor in verhale, en dít brei die lesers se lees- en lewensvaardighede uit.

Hierdie artikel het slegs gefokus op die toepassing van 'n voorgestelde humormodel op verhale vir lesers van nege tot twaalf jaar, asook die kernaspekte van die fasilitering daarvan in die tersiêre fase (onder andere talemodules en vakdidaktiekmodules) en die kernaspekte van die fasilitering daarvan in die intermediêre fase. Tog is hierdie humormodel vir die ondersoek van enige literatuur vir enige ouderdomsgroep - ook volwasseneliteratuur - bruikbaar. Die model kan toegepas word op verhale vir ander teikengroepe, verhale uit die oeuvres van een of meer outeurs en verder op verhale en ander genres in enige taal waarin daar alleen of saam met ander gelag kan word.

\section{Geraadpleegde bronne}

ATTARDO, S. 1994. Linguistic theories of humour. New York: De Gruyter.

BAUDOIN, T. 1994. Jeugdliteratuur voor de beroepspraktijk. Groningen: Wolters-Noordhoff. 
BERGSON, H. 1911. Laughter: an essay on the meaning of the comic. New York: Macmillan.

BRAUDE, S. 1996. The implications for humour in children's literature, with particular reference to the contemporary South African situation. (In Machet, M., Olën, S. \& Van der Walt, T., eds. Other worlds, other lives: Children's literature experiences. Proceedings of the International Conference on Children's Literature, Pretoria, 4-6 April 1995. Pretoria: Unisa. p. 94-106.)

CLOETE, T.T., red. 1992. Literêre terme en teorieë. Pretoria: HAUM-Literêr. (Reeks A: nr. 50.)

DE STERCK, M. 1997. Lees je mee? Een gids voor wie boeken en kinderen wil samenbrengen. Tielt: Lannoo.

DE VILLIERS, L. 1996. Aliens en engele. Kaapstad: Tafelberg.

DE VOS, P. 1990. Vincent van Gogga. Kaapstad: Tafelberg.

DEPARTEMENT VAN ONDERWYS. 2002. Revised National Curriculum Statements. Mrt.

DURANT, J. \& MILLER, J., eds. 1988. Laughing matters: A serious look at humour. Essex: Longman.

GLAZER, G.I. \& WILLIAMS III, G. 1979. Introduction to children's literature. New York: McGraw-Hill.

GORDON, L. 1996. Revolting rhymes: Humour as a subversive activity in children's literature. (In Hattingh, M. \& Willemse, H., reds. Vernuwing in die Afrikaanse letterkunde: referate gelewer tydens die sesde hoofkongres van die Afrikaanse Letterkundevereniging. Port Elizabeth, 29 Sept.-1 Okt. 1994. p. 203-218.)

GRUNER, C.R. 1978. Understanding laughter. The workings of wit and humour. Chicago: Nelson-Hall.

HULSKER, J., samest. 1998. Vincent van Gogh: een leven in brieven. Amsterdam: Meulenhoff.

JORDAAN, W. 2000. Die (volks)nar is dood - lank lewe die nar. Beeld: 23, Aug. 12.

LOUW, D.A., VAN EDE, D.M. \& LOUW, A.E. 1998. Menslike ontwikkeling. Pretoria: Kagiso.

LOWIS, M.J. \& NIEUWOUDT, J.M. 1994. Humor as a coping aid for stress. Social Work/Maatskaplike Werk, 30(2):124-131.

MARAIS, J.L. 1990. Groen: gedigte oor die omgewing. Pretoria: HAUM-Literêr.

MARAIS, J.L. \& ZUIDERENT, A. 1997. Ons klein en silwerige planeet. Pretoria: Van Schaik.

MIKKELSEN, N. 2000. Words and pictures: Lessons in children's literature and literacies. Boston: McGraw-Hill.

NATIONAL RESEARCH FOUNDATION. 2002. National Research Foundation/ Focus Areas/Education and the challenges for change. http://www. nrf.ac.za/focusareas/educate/ [18 Maart 2002].

NELSON SPIVEY, N. 1997. The constructivist metaphor: Reading, writing, and the making of meaning. New York: Academic Press.

PODILCHAK, W. 1992. Fun, funny, fun-of-humor and laughter. Humor, $5(4): 375-396$.

PRELLER, M. 1997. 'n Haas moet doen wat 'n haas moet doen. 2 de druk. Kaapstad: Human \& Rousseau.

RASKIN, V. 1985. Semantic mechanisms of humor. Dordrecht: Reidel. 
STEENBERG, E. 1987. Fantasie in die kinderboek - 'n kernhandleiding. Pretoria: HAUM-Literêr.

TUCKER, N. 1988. What's the joke? A look at children's humour. (In Durant, J. \& Miller, J., eds. Laughing matters: A serious look at humour. Essex: Longman. p. 66-74.)

VAN COILLIE, J. 1999. Leesbeesten en boekenfeesten: hoe werken (met) kinder- en jeugdboeken? Leuven: Davidsfonds/Infodok.

VAN DER WESTHUIZEN, B. 1999. 'n Polisistemiese benadering tot die bevordering van kleuter-, kinder- en jeugliteratuur. Stilet, 9(1):125-139.

VAN GORP, H., GHESQUIERE, R., DELABASTITA, D. \& FLAMEND, J., reds. 1991. Lexicon van literaire termen. Groningen: Wolters-Noordhoff.

VAN NIEKERK, J.E. 2001. Humor in kinderverhale: 'n vergelyking tussen geselekteerde Afrikaanse en Nederlandse tekste. Potchefstroom: PU vir CHO. (M.A.-verhandeling. )

WALTHER, I.F. \& METZGER, R. 2001. Van Gogh: alle schilderijen. Köln: Taschen.

WHITE, S. \& WINZELBERG, A. 1992. Laughter and stress. Humor, 5(4):343355.

WOOLFOLK, A. 1998. Educational psychology. Boston: Allyn \& Bacon.

\section{Kernbegrippe:}

De Villiers, Leon: Aliens en engele (1996)

De Vos, Philip: Vincent van Gogga (1990)

humor, kinder- en jeugliteratuur

humormodel as vakdidaktiewe middel: intermediêre en tersiêre fase Preller, Martie: 'n Haas moet doen wat 'n haas moet doen (1997)

\section{Key concepts:}

De Villiers, Leon: Aliens en engele (1996)

De Vos, Philip: Vincent van Gogga (1990)

humour, children's and youth literature

humour model as didactic tool in the intermediate and tertiary phase Preller, Martie: 'n Haas moet doen wat 'n haas moet doen (1997) 
